\title{
HUBUNGAN MEKANISME KOPING DENGAN KUALITAS HIDUP PADA PENDERITA DIABETES MELITUS TIPE 2 DI RS ROEMANI SEMARANG
}

\author{
Riska Novi Asafitri ${ }^{1}$, Faridah Aini $^{2}$, Yunita Galih ${ }^{3}$ \\ Program S1 Keperawatan, Universitas Ngudi Waluyo, Ungaran \\ Email: nriska646@gmail.com
}

\begin{abstract}
ABSTRAK
Keberhasilan penggunaan koping efektif pada penyandang diabetes melitus akan berdampak pada kepatuhan penyandang dalam terapi diabetes melitus yang pada akhirnya kadar glukosa darah penyandang diabetes melitus dapat diturunkan. Mekanisme koping yang efektif diperlukan untuk mengurangi stress, menjaga hubungan sosial individu, mempertahankan konsep diri yang positif sehingga dapat memelihara kualitas hidup yang baik. Penelitian ini bertujuan untuk mengetahui hubungan mekanisme koping dengan kualitas hidup pada penderita diabetes melitus tipe 2 di RS Roemani Semarang. Desain penelitian ini adalah deskriptif korelasi dengan menggunakan pendekatan cross sectional. Populasi penelitian ini adalah penderita DM tipe 2. Sampel dalam penelitian ini sebanyak 61 orang dengan teknik accidental sampling. Alat pengambilan data untuk mekanisme koping diukur menggunakan The Brief COPE, untuk kualitas hidup diukur menggunakan WHOQOL-BREF. Uji statistik menggunakan Chi-Square. Hasil penelitian ini menunjukkan mekanisme koping pada penderita DM tipe 2 lebih dari separo kategori adaptif 39 orang (63,9\%), kualitas hidup pada penderita DM tipe 2 lebih dari separo kategori baik 35 orang $(57,4 \%)$. Ada hubungan yang signifikan antara mekanisme koping dengan kualitas hidup pada penderita diabetes melitus tipe 2 di RS Roemani Semarang, hasil uji didapatkan $p$-value sebesar $0,006<(\alpha=0,05)$. Penderita diabetes melitus dapat meningkatkan strategi koping adaptif dapat dilakukan dengan berpikir positif, lebih mendekatkan diri kepada Allah SWT dengan sholat, dzikir, beramal, puasa, dan lain-lain.
\end{abstract}

Kata Kunci : Mekanisme Koping, Kualitas Hidup, Diabetes Melitus

\section{ABSTRACT}

The Correlation between Coping Mechanism and Quality of Life in Patients with Diabetes Mellitus Type 2 at Roemani Hospital Semarang

The success of effective coping use in people with diabetes mellitus will have an impact on the compliance of persons in the treatment of diabetes mellitus, which ultimately can lower the blood glucose levels of people with diabetes mellitus. Effective coping mechanisms are needed to reduce stress, maintain individual social relationships, maintain a positive self-concept so as to maintain a good quality of life. To know the correlation between coping mechanisms with quality of life in patients with type 2 diabetes mellitus at Roemani Hospital Semarang. The design of this study is descriptive correlation using a cross sectional approach. The population of this study was type 2 DM patients. The samples in this study were 61 people using accidental sampling technique. The data collection tool for coping mechanisms was measured by using The Brief COPE, for quality of life was measured by using WHOQOL-BREF. Statistical tests used Chi-Square. The results of this study showed that coping mechanisms in Hubungan Mekanisme Koping.. (Riska Novi Asafitri, Faridah Aini) 
patients with type 2 diabetes mellitus were mostly in adaptive categories of 39 people (63.9\%), the quality of life in patients with type 2 diabetes mellitus was mostly good category of 35 people (57.4\%). There was a significant correlation between coping mechanism and quality of life in patients with type 2 diabetes mellitus at Roemani Hospital Semarang, the test results obtained p-value of $0.006<(\alpha=0.05)$ Patients with diabetes mellitus can improve adaptive coping strategies can be done by positive thinking, closer to Allah SWT with prayer, remembrance, charity, fasting, etc.

\section{Keywords : coping mechanism, quality of life, diabetes melitus}

\section{PENDAHULUAN}

Prevalensi orang dengan diabetes di Indonesia menunjukkan kecenderungan meningkat yaitu dari 5,7\% (2007) menjadi 6,9\% (2013). Berdasarkan hasil rekapitulasi data kasus baru PTM (Penyakit Tidak Menular), jumlah kasus baru yang dilaporkan secara keseluruhan pada tahun 2015 adalah 603.840 kasus. Penyakit diabetes melitus menjadi urutan kedua penyakit PTM terbesar setelah hipertensi, sebesar 18,33 persen penderita diabetes melitus (Profil Dinkes Jateng, 2015). Angka penyakit Diabetes Militus (DM) di kota Semarang terus meningkat setiap tahun. Pada 2012 ada 8.725 kasus dan pada 2013 meningkat menjadi 14.207 kasus.

Pasien diabetes melitus yang disertai komplikasi akan membebani dalam menangani atau mengontrol kualitas hidup walaupun keadaan diabetes melitus lama dideritanya. Komplikasi diabetes melitus merupakan faktor yang paling menentukan kualitas hidup pasien diabetes melitus (Choi, dkk 2011).

Salah satu dari tujuan akhir pengelolaan diabetes melitus yaitu terpeliharanya kualitas hidup yang baik bagi pasien diabetes melitus. Untuk mencapai kualitas hidup yang baik diperlukan kerja keras dan konsistensi yang tinggi pada penderta diabetes melitus. Mekanisme koping merupakan cara yang dilakukan individu dalam menyelesaikan masalah, menyesuaikan diri dengan perubahan, serta respons terhadap situasi yang mengancam (Nasir
\& Muhith, 2011). Keberhasilan koping pada penyandang diabetes melitus dipengaruhi banyak faktor antara lain pengalaman keluarga dengan diabetes melitus, penerimaan terhadap penyakitnya, dan persepsi penyandang terhadap penyakitnya menjadi modal berhasil atau tidaknya tergantung koping yang dilakukan (Hidayat, 2013).

Berdasarkan penelitian yang dilakukan oleh yousaf, dkk (2016) tentang "Self Care, Coping Strategies and Quality of Life of Individuals With Diabetes" dan meifianto (2016) tentang "Hubungan Strategi Coping Dan Kualitas Hidup Dalam Diabetes Melitus Tipe 2 Pasien Di Wilayah Kerja Puskesmas Mulyorejo Surabaya" menyimpulkan bahwa ada hubungan yang signifikan antara strategi koping dengan kualitas hidup.

Berdasarkan hasil studi pendahuluan yang dilakukan di RS Roemani Semarang tanggal 3 November 2018 didapatkan hasil dengan 5 orang pasien, 3 dari 5 pasien memiliki mekanisme koping adaptif dan 2 dari 5 pasien memiliki mekanisme koping mal adaptif. 2 dari 3 pasien yang memiliki mekanisme koping adaptif menyatakan bahwa kualitas hidup baik, sedangkan 1 dari 3 pasien yang memiliki mekanisme koping adaptif menyatakan bahwa kualitas hidupnya sedang. 1 dari 2 pasien yang memiliki mekanisme mal adaptif menyatakan bahwa kualitas hidupnya sedang, dan 1 dari 2 pasien yang memiliki mekanisme koping mal adaptif menyatakan kualitas hidupnya buruk. 


\section{METODE PENELITIAN}

Penelitian ini menggunakan desain deskriptif korelasi dengan menggunakan pendekatan cross sectional. Populasi dalam penelitian ini penderita diabetes melitus tipe 2 di rawat jalan RS Roemani Semarang dengan jumlah sampel yang diteliti sebanyak 61 orang, metode pengambilan sampel dalam penelitian ini adalah accidental sampling. Alat ukur yang digunakan adalah The BriefCOPE dan WHOQOL-BREF. Analisis data yang digunakan menggunakan uji Chi Square.

\section{HASIL DAN PEMBAHASAN}

1. Gambaran Mekanisme Koping Penderita Diabetes Melitus Tipe 2 di RS Roemani Semarang

Tabel. 1 Distribusi Frekuensi

Berdasarkan Mekanisme Koping Penderita Diabetes Melitus Tipe 2 di RS Roemani Semarang

\begin{tabular}{lcc}
\hline $\begin{array}{l}\text { Mekanisme } \\
\text { Koping }\end{array}$ & f & \% \\
\hline Mal adaptif & 22 & 36,1 \\
Adaptif & 39 & 63,9 \\
\hline
\end{tabular}

\begin{tabular}{lll}
\hline Jumlah & 61 & 100,0 \\
\hline
\end{tabular}

Berdasarkan tabel 1 menunjukkan bahwa mekanisme koping penderita diabetes melitus tipe 2 di RS Roemani Semarang lebih dari seeparo kategori adaptif yaitu sebayak 39 dari 61 responden $(63,9 \%)$.

2. Gambaran Kualitas Hidup Penderita Diabetes Melitus Tipe 2 di RS Roemani Semarang

Tabel. 2 Distribusi Frekuensi Berdasarkan Kualitas Hidup

Penderita Diabetes Melitus Tipe 2 di RS Roemani Semarang

\begin{tabular}{ccc}
\hline $\begin{array}{c}\text { Kualitas } \\
\text { Hidup }\end{array}$ & f & \% \\
\hline Sedang & 26 & 42,6 \\
Baik & 35 & 57,4 \\
\hline Jumlah & 61 & 100,0 \\
\hline
\end{tabular}

Berdasarkan tabel 2 menunjukkan bahwa kualitas hidup penderita diabetes melitus tipe 2 di RS Roemani Semarang sebagian besar kategori baik yaitu sebayak 35 dari 61 responden $(57,4 \%)$.

3. Hubungan Mekanisme Koping Dengan Kualitas Hidup Pada Penderita Diabetes Melitus Tipe 2 di RS Roemani Semarang

Tabel 3 Hubungan Mekanisme Koping Dengan Kualitas Hidup Pada Penderita Diabetes Melitus Tipe 2 di RS Roemani Semarang

\begin{tabular}{|c|c|c|c|c|}
\hline \multirow{3}{*}{$\begin{array}{c}\text { Mekanisme } \\
\text { Koping }\end{array}$} & \multicolumn{4}{|c|}{ Kualitas Hidup } \\
\hline & Sedang & Baik & Total & \multirow{2}{*}{$\begin{array}{c}\text { Chi } \\
\text { Square }\end{array}$} \\
\hline & $\%$ & $\%$ & $\%$ & \\
\hline Mal adaptif & 1568,2 & $7 \quad \mathbf{3 1 , 8}$ & 22100 & 0.006 \\
\hline Adaptif & 1128,2 & 2871,8 & 39100 & 0,000 \\
\hline Jumlah & 2642,6 & $35 \quad 57,4$ & 61100 & \\
\hline
\end{tabular}

Berdasarkan hasil analisis hubungan mekanisme koping dengan kualitas hidup pada penderita diabetes melitus tipe 2 di RS Roemani Semarang, diperoleh hasil bahwa responden dengan mekanisme koping mal adaptif sebanyak 22 orang dimana lebih dari separo mempunyai kualitas hidup kategori sedang yaitu sebanyak 15 orang $(68,2 \%)$ lebih banyak dari pada yang mempunyai 
kualitas hidup kategori baik yaitu sebanyak 7 orang $(31,8 \%)$. Responden dengan mekanisme koping adaptif sebanyak 39 orang dimana lebih dari separo mempunyai kualitas hidup kategori baik yaitu sebanyak 28 orang $(71,8 \%)$ lebih banyak dari pada yang mempunyai kualitas hidup kategori sedang yaitu sebanyak 11 orang $(28,2 \%)$. Hasil uji statistik dengan menggunakan uji chi square didapatkan p-value sebesar $0,006<\alpha(0,05)$. Hal ini dapat disimpulkan bahwa ada hubungan yang signifikan antara mekanisme koping dengan kualitas hidup pada penderita diabetes melitus tipe 2 di RS Roemani Semarang.

\section{PEMBAHASAN}

\section{Gambaran Mekanisme Koping Penderita Diabetes Melitus Tipe 2 di RS Roemani Semarang}

Berdasarkan hasil penelitian menunjukkan mekanisme koping pada penderitas diabetes melitus tipe 2 sebagian besar adalah dalam kategori adaptif sebanyak 39 orang $(63,9 \%)$, sedangkan mekanisme koping maladaptif sebanyak 22 orang $(36,1 \%)$. Mekanisme koping responden kategori adaptif pada pertanyaan 27 dimana sebanyak 32 responden $(52,5 \%)$ menyatakan penyakit diabetes melitus merupakan ujian dari Allah SWT dan selalu berdoa agar diberi kesembuhan, pertanyaan nomer 23 dimana sebanyak 29 responden $(47,8 \%)$ menyatakan bahwa sering mendapat dukungan dan saran dari keluarga maupun teman dekat dalam menghadapi masalah yang sedang terjadi.

Responden melakukan koping terhadap masalah yang dihadapi dengan mencoba menerima apa yang di hadapi. Mereka pasrah terhadap masalah yang dihadapi menyerahkan sepenuhnya kepada Tuhan. Karena mereka yakin Tuhan maha kuasa yang dapat menyelesaikan permasalahan yang dihadapi. Aspek emosional serupa yang dilakukan responden selain penerimaan adalah kembali pada agama dengan berdoa untuk mendekatkan diri kepada Tuhan. Dalam hal ini faktor religius atau keyakinan mendasari responden melakukan koping dengan kembali pada agama. Penelitian yang dilakukan Shamsalinia (2015) membuktikan bahwa koping religius positif memiliki efek yang signifikan pada tingkat harapan. Dukungan dari keluarga berupa dorongan untuk selalu melakukan kontrol rutin atau dengan sama - sama mengikuti perubahan pola hidup penderita yang berubah akibat diabetes melitus. Melalui dukungan dari keluarga, penderita menjalankan manajemen diabetes melitus dengan lebih patuh. Hasil penelitian dari Yanes P. Taluta (2014) menunjukan 20 responden $(62,5 \%)$ memiliki mekanisme koping adaptif.

Mekanisme koping penderita diabetes melitus tipe 2 RS Roemanis Semarang pada indikator humor ditunjukan dengan pernyataan responden yang kadang-kadang menonton hal-hal yang lucu di TV untuk mengurangi rasa takut dan cemas $(32,8 \%)$.

Menurut Siswanto (2009), humor merupakan kemampuan untuk melihat segi yang lucu dari persoalan yang sedang dihadapi, sehingga perspektif persoalan tersebut menjadi lebih luas, terang dan tidak dirasa sebagai menekan lagi ketika dihadapi dengan humor. Menurut Lestari (2015) ada beberapa faktor yang mempengaruhi mekanisme koping, diantaranya yaitu pendidikan. Seseorang dengan tingkat pendidikan yang semakin tinggi akan semakin tinggi pula kompleksitas kognitifnya, demikian pula sebaliknya.

\section{Gambaran Kualitas Hidup Penderita Diabetes Melitus Tipe 2 di RS Roemani Semarang}

Berdasarkan hasil penelitian diketahui bahwa dari 61 responden 
dengan kualitas hidup sedang 26 responden $(42,6 \%)$, dan yang mempunyai kualitas hidup baik 35 responden $(57,4 \%)$. Kualitas hidup dengan kategori sedang pada indikator fisik $(69,2 \%)$, indikator kesejahteraan psikologis $(65,4 \%)$, indikator hubungan sosial $(88,5 \%)$, indikator lingkungan $(65,4 \%)$. Kualitas hidup dengan kategori baik pada indikator fisik dan kesejahteraan psikologis $(57,1 \%)$, indikator hubungan sosial $(85,7 \%)$ ditunjukan dengan respon menyatakan puas dengan hubungan personal/sosial, indikator lingkungan $(91,4 \%)$.

Kualitas hidup penderita diabetes melitus tipe 2 dalam kategori sedang dimana mereka merasa tidak dapat menikmati hidup karena harus mengkonsumsi obat setiap hari dan menjalani perawatan jalan. Beberapa responden juga memiliki perasaan negatif seperti feeling blue (kesepian), putus asa, cemas dan depresi karena harus menjalani perawatan medis dalam jangka waktu yang lama.

Salah satu aspek dalam kualitas hidup yaitu hubungan sosial salah satu contohnya yaitu menghadiri pengajian atau kajian keagamaan. Aspek ini dapat berperan dalam peningkatan kualitas hidup dimana individu yang secara rutin menghadiri pengajian maupun kajian keagamaan akan sering bertemu dengan orang lain. Secara tidak langsung individu tersebut memiliki hubungan sosial yang baik dan dapat memperoleh dukungan sosial dari orang-orang disekitarnya sehingga berdampak pada peningkatan kualitas hidup individu tersebut. Hal ini dibuktikan dengan penelitian yang dilakukan Al-Adawi dkk (2011) yang menyebutkan bahwa dukungan sosial mampu memberdayakan pasien, dapat meningkatkan kualitas hidup serta mengurangi keparahan penyakit.

Kualitas hidup penderita diabetes melitus tipe 2 di RS Roemani Semarang kategori baik ditunjukkan dengan responden yang menjawab kemampuan dalam bergaul tetap baik sebanyak 26 responden $(42,6 \%), 24$ responden $(39,3 \%)$ puas dengan dukungan yang diperoleh dari teman dan keluarga yang merupakan salah satu faktor dalam meningkatkan kualitas hidup pasien diabetes melitus. Dukungan penghargaan yang diberikan oleh keluarga terhadap pasien diabetes melitus tipe 2 dapat meningkatkan status psikososial, semangat, motivasi dan peningkatan harga diri karena dianggap masih berguna dan berarti untuk keluarga sehingga membentuk perilaku penatalaksanaan DM secara teratur yang bermuara pada peningkatan kualitas hidup.

\section{Hubungan Mekanisme Koping Dengan Kualitas Hidup Pada Penderita Diabetes Melitus Tipe 2 di RS Roemani Semarang}

Berdasarkan hasil analisis hubungan mekanisme koping dengan kualitas hidup pada penderita diabetes melitus tipe 2 di RS Roemani Semarang, diperoleh hasil bahwa responden dengan mekanisme koping mal adaptif sebanyak 22 orang dimana sebagian besar mempunyai kualitas hidup kategori sedang yaitu sebanyak 15 orang $(68,2 \%)$ lebih banyak dari pada yang mempunyai kualitas hidup kategori baik yaitu sebanyak 7 orang $(31,8 \%)$.

Responden dengan mekanisme koping adaptif sebanyak 39 orang dimana sebagian besar mempunyai kualitas hidup kategori baik yaitu sebanyak 28 orang $(71,8 \%)$ lebih banyak dari pada yang mempunyai kualitas hidup kategori sedang yaitu sebanyak 11 orang $(28,2 \%)$. Kondisi ini dapat digambarkan bahwa responden lebih berhati - hati dalam mengatur pola makan yang sesuai dengan diitnya, selalu melakukan pemeriksaan secara berkala pada penyakit diabetes melitus. Hasil ini dipengaruhi oleh mekanisme 
koping yang digunakan sehingga dapat mempengaruhi kualitas hidup penderita diabetes melitus tipe 2 .

Hidup dengan diabetes menyebabkan stres, hal ini akan menimbulkan efek pada kualitas hidup (Shahab, 2010). Pada penderita diabetes kualitas hidup merupakan tujuan utama perawatan, sebisa mungkin kualitas hidup yang baik harus dipertahankan pada penderita diabetes mellitus, karena kualitas hidup yang rendah serta problem psikologis dapat memperburuk gangguan metabolik, baik secara langsung melalui stres hormonal ataupun secara tidak langsung melalui komplikasi (Mandagi, 2010). Mukwato, dkk (2010) mengatakan mekanisme koping yang baik ada empat yang meliputi (a) dukungan sosial, (b) spiritual, (c) sikap atau pemikiran yang positif, dan (d) mendapatkan informasi atau pendidikan.

Kualitas hidup juga merupakan salah satu faktor penting yang dapat mempengaruhi kondisi kesehatan seseorang. Kualitas hidup yang buruk akan semakin memperburuk kondisi suatu penyakit, begitu pula sebaliknya, suatu penyakit dapat menyebabkan terjadinya penurunan kualitas hidup seseorang, terutama penyakit-penyakit kronis yang sangat sulit disembuhkan salah satunya seperti diabetes mellitus. Hasil penelitian ini didukung dari penelitian Arina Fithriyatina (2018) didapatkan hasil bahwa ada hubungan yang signifikan antara strategi koping dengan kualitas hidup pada pasien diabetes melitus tipe 2 dengan $\mathrm{p}$ value 0,005 , semakin tinggi strategi koping yang digunakan maka cenderung tinggi pula kualitas hidup pada pasien diabetes melitus tipe 2 .

Hasil uji statistik dengan menggunakan uji chi square didapatkan $p$-value sebesar 0,006. Karena p-value $0,006<\alpha(0,05)$, maka $\mathrm{H}_{0}$ ditolak. Hal ini dapat disimpulkan bahwa ada hubungan yang signifikan mekanisme koping dengan kualitas hidup pada penderita diabetes melitus tipe 2 di RS Roemani Semarang. Koping yang efektif sering kali bervariasi sesuai situasi. Satu mekanisme koping mungkin efektif untuk mengatasi suatu masalah namun belum tentu efektif dengan masalah lain. Kualitas hidup yang baik dapat mempermudah proses pengobatan DM.

Hal ini di dukung oleh hasil penelitian Mandagi (2012) yang mengatakan bahwa kualitas hidup merupakan salah satu tujuan utama dalam perawatan, khususnya pada penderita DM. Apabila kadar gula darah dapat terkontrol dengan baik maka keluhan fisik akibat komplikasi akut ataupun kronis dapat dicegah.

Strategi koping yang baik dapat menghasilkan kualitas hidup yang baik dan menghasilkan suatu tindakan yang positif. Sebaliknya, apabila strategi koping yang digunakan tidak sesuai dapat menghasilkan kualitas hidup yang kurang baik dan dapat mengalami distress psikologis yang berat. Hasil penelitian ini sesuai dengan penelitian dari rui coelho, dkk (2009) tentang "Coping Styles and Quality of Life in Patients With Non-Insulin-Dependent Diabetes Mellitus" di dapatkan hasil bahwa adanya korelasi yang signifikan (pvalue 0,02) strategi koping dengan beberapa dimensi kualitas hidup pada pasien diabetes.

\section{KETERBATASAN PENELITIAN}

Keterbatasan dari penelitian ini diantaranya penelti tidak dapat mengendalikan faktor dari mekanisme koping seperti dukungan sosial, keyakinan atau pandangan positif, tingkat pendidikan, keterampilan sosial.

\section{KESIMPULAN}

Berdasarkan hasil penelitian dan pembahasan mengenai hubungan mekanisme koping dengan kualitas hidup pada penderita diabetes melitus 
tipe 2 di RS Roemani Semarang. Maka di dapatkan beberapa kesimpulan yaitu responden yang menggunakan mekanisme koping adaptif sebanyak 39 orang $(63,9 \%)$ dari 61 responden, sedangkan responden yang memiliki kualitas hidup baik sebanyak 35 orang $(57,4 \%)$ dari 61 responden. Ada hubungan yang signifikan antara mekanisme koping dengan kualitas hidup pada penderita diabetes melitus tipe 2 di RS Roemani Semarang dengan $p$ value $0,006<(\alpha=0,05)$.

DAFTAR PUSTAKA

Dinkes Prov Jateng. 2015. Profil Kesehatan Provinsi Jawa Tengah Tahun 2015. Semarang.

Mandagi, A. M. 2010. Faktor Yang berhubungan Dengan Status Kualitas hidup penderita Diabetes Mellitus. Jurnal Penelitian Kesehatan. Fakultas kesehatan Universitas Airlangga Surabaya.

Mukwato, dkk. 2010. Stress and Coping mechanisms Among Breast Cancer Patients and Family
Caregivers. Diakses pada tanggal 4 februari 2019.

Nasir, A \& Muhith, A. 2011. Dasar Dasar Keperawatan Jiwa. Jakarta : Salemba Medika.

Suni, Arina Fithriyatina. 2018. Hubungan Antara Strategi Coping Dengan Kualitas Hidup Pada Pasien Diabetes Melitus Tipe 2. Diakses pada tanggal 17 juli 2019.

Yanes, P. Taluta, dkk. 2014. Hubungan Tingkat Kecemasan Dengan Mekanisme Koping Pada Penderita Diabetes Melitus Tipe II Di Poliklinik Penyakit Dalam Rumah Sakit Umum Daerah Tobelo Kabupaten Halmahera Utara. Diakses pada tanggal 18 Juli 2019.

Yousaf, M. K. R., \& Kausar R. 2016. Self Care, Coping Strategies and Quality of Life of Individuals With Diabetes. Journal of Behavioural Sciences, 26(1), 17-31. 